\title{
spotlight
}

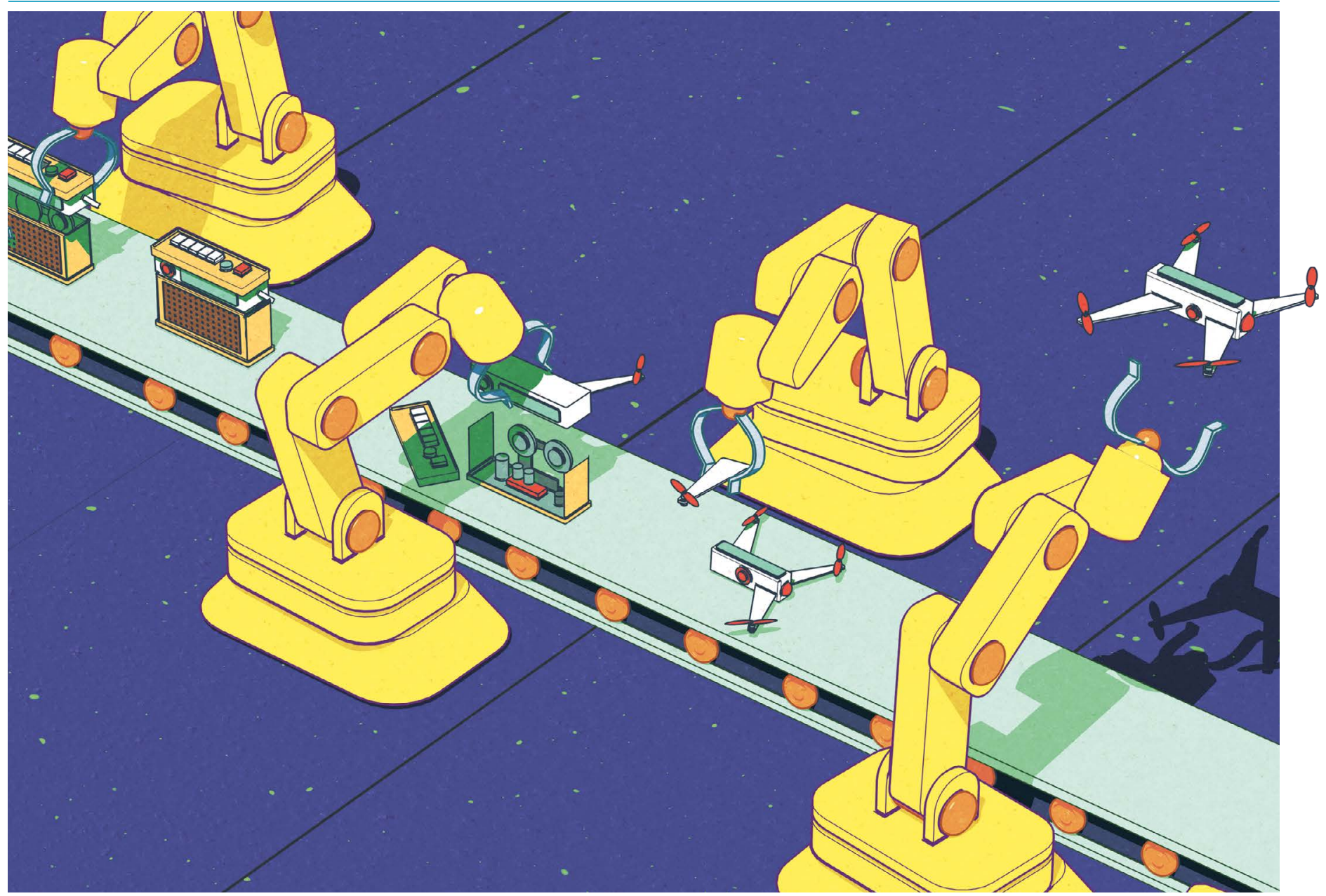

\section{TAIWAN'STIME TOTRANSFORM}

The government is betting its manufacturing future on smart machinery and artificial intelligence to improve product quality and flexibility. By Sarah O'Meara

n2016, industrial engineer Chen-Fu Chien was asked to lead a university research centre in Taiwan that would develop new manufacturing technologies using artificial intelligence (AI).

Rather than aiming to publish academic papers, his brief was to produce ideas that could be quickly transferred into industrial settings, says Chien. His research at the National Tsing Hua University (NTHU) in Hsinchu City uses big-data analytics to make machines smarter through Al that lets them take decisions without human control. It is one of several approaches to creating 'smart factories' that use an interconnected, digital network of supply systems - part of Taiwan's push to improve the flexibility, quality and efficiency of its manufacturing.

"I am one of the few senior scientists in Taiwan who's worked extensively with business, as well as in public research. It's one of the reasons the government asked me to lead the project," says Chien, whose position at the NTHU is endowed by the US firm Micron Technology in Boise, Idaho, which develops computer memory and storage technologies. Chien's mission is a sign of how Taiwan's government wants its manufacturing industry to change using technologies such as cloud computing, big data, the Internet of Things and smart robots - a shift in industrial practices that has been dubbed Industry 4.0. Once known as a hub for mass-produced cheap goods, such as toys and electronics carrying the ubiquitous 'Made in Taiwan' stamp, the island is looking to science to upgrade its image so it can become a destination for international companies searching for futuristic manufacturing solutions.

In 2018, Chien and his team opened the Artificial Intelligence for Intelligent 


\section{spotlight}

Manufacturing Systems (known as AIMS) research centre in Hsinchu. The laboratory has more than 50 staff members and Chien is responsible for 10 related projects in other research institutes across Taiwan. It is part of a wider initiative begun in 2018 that includes three further facilities developing AI technologies in areas such as financial technology, health care and intelligent transportation systems. The whole initiative will cost the Taiwanese government around US $\$ 33$ million over 5 years.

“The Ministry of Science and Technology wanted our centre to help create the next generation of intelligent manufacturing systems that could only be found in Taiwan," Chien says. The ministry's aim is “to use the region's strength in electronics manufacturing to its best advantage and establish Taiwan as a key high-tech manufacturing hub".

Taiwan's efforts to change its manufacturing model are timely. A global slowdown in trade since 2011 and a tariff war on goods traded between mainland China and the United States have pushed companies to look for alternative manufacturing options that are flexible, efficient and unaffected by such economic tussles.

\section{Diverse development}

Taiwan has been a leading manufacturer of electronic components since the 1990s. Its economy remains reliant on an industry that is led by the world's largest contract electronic chipmaker, Taiwan Semiconductor Manufacturing Company (TSMC), which supplies technology companies such as Apple and Huawei and contributed more than $4 \%$ to the region's gross domestic product in 2018.

However, the growth of consumer electronics has slowed across the world in the past few years: many people already have smartphones, and so fewer are being bought. In 2016, Taiwan's newly inaugurated president, Tsai Ingwen, announced that the government would promote a new model of economic development. The idea was to encourage local technology firms to diversify their products and to become more innovative and self-sufficient to boost technology ties with the United States and Japan. Taiwan also wants to reduce its reliance on mainland China (see 'Moving money').

\section{"Companies need to make manufacturing more intelligent so it can be more flexible."}

Tsai's 2016 strategy was followed by a breakneck series of policy announcements to encourage investment in smart machinery equipment that can work with less input from an expensive human controller - and in other manufacturing technologies (see 'Non-stop reforms').

When Taiwanese manufacturers began moving factories to mainland China in the 2000s, it harmed the development of smart manufacturing technology on the island, explains Stephen Su, who runs a centre at Taiwan's Industrial Technology Research Institute (ITRI), a government-funded research and development centre in Hsinchu. The institute, founded in 1973, has acted as an incubator for several Taiwanese companies, including the TSMC.

Now the government is "pouring resources" into smart manufacturing "because it's the future of production", Su says.

A conventional moving assembly line many people using tools to complete small tasks in a much larger, complex process - was pioneered by Henry Ford to manufacture automobiles in the United States in 1913. Invented at the end of the 'second industrial revolution' that saw the global spread of technologies such as electrical power, the assembly line is still used in many factories today, says Chien.

Machines have largely replaced workers since the advent of the computer age, which saw a third revolution in industry involving robotics and greater automation. The next development, known as the fourth industrial revolution or Industry 4.0, will use advances in cyber-physical systems, such as optical-fibre sensors on machines. These will collect and exchange data that can be processed by bigdata analytics and AI technologies, enabling manufacturers to make flexible decisions about how they operate and to allocate resources efficiently to empower smart production. Taiwan is betting that the products of the future will be made by such intelligent machinery.

Companies around the world are similarly re-evaluating where and how they make their products, says Jason Ho, general manager of Avectec in Zhubei City near Hsinchu, which offers conventional manufacturers a software platform to help create smart factories. In these, networked machines can detect their own faults, work more efficiently and reduce production costs.

"Particularly in high-tech areas such as the computer industry, information and communications technology and consumer electronics, companies don't need to focus on making more products more quickly. They need to make manufacturing more intelligent so it can be more flexible. That way, companies can quickly adjust the product to meet the demands of each customer," Ho says.

\section{Talent base}

Now that Taiwan is remaking itself as a destination for the next generation of manufacturers, there's one thing it requires more of: talent.

It is in urgent need of experienced engineers, both to design smart manufacturing technologies and to create the high-tech products of the future, says Su. "We must invest in our scientists and engineers. There are many countries in southeast Asia that are also becoming more sophisticated in terms of manufacturing, and to stay competitive, it's important to make investments in education," says Su.

\begin{tabular}{l|l} 
NON-STOP & $\begin{array}{l}\text { May } 2016 \\
\text { Taiwan's government } \\
\text { announces its 'Five } \\
\text { plus two' policy -a } \\
\text { plan to innovate in the } \\
\text { fields of biotechnology, } \\
\text { defence, green energy, } \\
\text { intelligent machinery } \\
\text { and the Internet of } \\
\text { Things. }\end{array}$ \\
TOCHS
\end{tabular}

\begin{tabular}{|c|c|c|}
\hline $\begin{array}{l}\text { November } 2016 \\
\text { Launch of the Digital } \\
\text { Nation and Innovative } \\
\text { Economic Development } \\
\text { Program (DIGI+), an } \\
\text { initiative to make Taiwan } \\
\text { a smart digital region by } \\
\text { 2025. Policies include } \\
\text { investment in start-up } \\
\text { firms and development } \\
\text { of the cybersecurity } \\
\text { industry. }\end{array}$ & $\begin{array}{l}\text { February } 2017 \\
\text { The Smart Machinery } \\
\text { Promotion Program } \\
\text { is introduced. It aims } \\
\text { to develop smart- } \\
\text { machinery applications } \\
\text { by combining } \\
\text { manufacturing } \\
\text { expertise with that } \\
\text { from information } \\
\text { and communications } \\
\text { technologies. }\end{array}$ & $\begin{array}{l}\text { July } 2017 \\
\text { The Ministry of Science } \\
\text { and Technology } \\
\text { (MOST) unveils plans to } \\
\text { establish four research } \\
\text { centres in artificial } \\
\text { intelligence (Al). The } \\
\text { initiative will cost } \\
\text { US } \$ 33 \text { million annually } \\
\text { over five years. }\end{array}$ \\
\hline
\end{tabular}

\section{November 2016}

Launch of the Digita

ation and Innovative Program (DIGI+), an initiative to make Taiwan smart digital region by firms and development of the cybersecurity industry.

\section{February 2017} is introduced. It aim to develop smartmachinery applications by combining from information and communications technologies.

\section{August 2017}

MOST announces a

4-year, \$132-million semiconductor programme to speed up the development of Al processor chips, and a 5-year, \$517.5-million strategy to cultivate Al talent and research (2017 to 2021). 
Mark Liu, chair of the TSMC, says the region's shortage of qualified engineers and other professionals could hamper the industry's development more than technological barriers.

Taiwan's government has acknowledged the severity of its talent deficit, and in 2018 passed legislation to help recruit and attract foreign professionals to work in Taiwan. Measures include the introduction of an employment gold card, a type of visa that entitles the holder to tax breaks, pension contributions and flexible residency options for family members. Of the 500 cards that were issued by the end of November 2019, just under one-fifth went to specialists in science and technology.

Su also points to the 2018 launch of an industry-funded organization called the Taiwan Al Academy, which started as one of the 11 project teams at the AIMS centre. It now has four campuses across Taiwan and runs 12-week courses for technical professionals or business managers working in the field who want to sharpen their skills. "Smart manufacturing with AI applications is one focus for the training curriculum," Su says. “Many large manufacturing conglomerates such as AUO, MediaTek and the Formosa Plastics Group have sent their engineers and managers there." (The academy lists these firms as sponsors on its website.)

Other initiatives will also spur the need for talent. In January 2019, the government announced a programme to encourage Taiwanese businesses located overseas to relocate home by offering incentives such as financial subsidies and administrative support. As this article went to press, 168 companies had pledged to return from mainland China. William Tang, a spokesperson from InvesTaiwan - the government agency in Taipei that runs the project - says those companies will together invest $\$ 200$ billion over three years in industrial infrastructure, such as factories, equipment and telecommunications technology, with an estimated $\$ 6.3$ billion spent in 2019 .

\section{From the ground up}

Mechavision in Taipei City, a spin-off company from ITRI that specializes in industrial robotic arms, is one of those hoping to capitalize on a growing need for more advanced production equipment both at home and abroad.

The three-year-old firm makes robotic tactile sensing technology for use where humans and robots collaborate in close quarters on the

\section{MOVING MONEY}

Taiwan has increased its investment in mainland China over the past three decades.

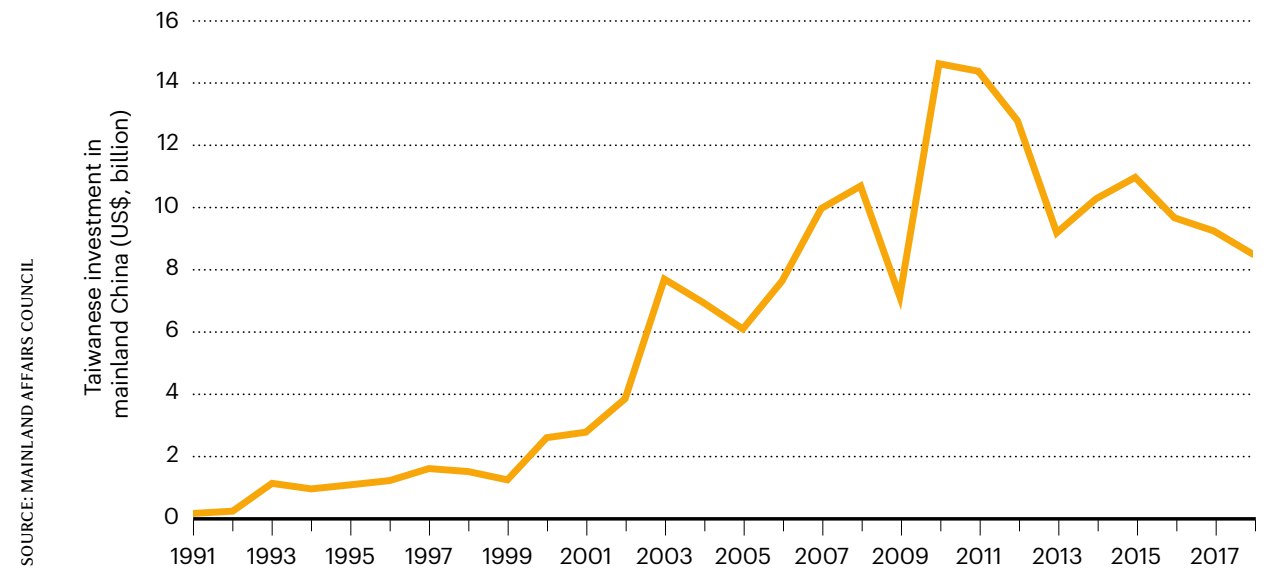

factory floor. For safety, the robots are fitted with an electronic skin that has tactile sensors, which allows the machines to detect workers nearby and so move away when necessary.

Mechavision's chief strategy officer and founder, Camus Su, says that one of the firm's main clients is Taiwanese company Qisda in Taoyuan City. It makes a variety of products, including computer monitors and mobile communication devices, so has opted for a mixed-line system that allows different models to be made on the same assembly line. The company needs "high flexibility in order to cope with different product sizes and specifications," he says, "and right now, our human-robot collaboration system is the best way to do this."

Min Sun, chief AI scientist at Appier, a Taiwanese company that uses AI to help enterprises solve business problems, says that in one respect, advanced computing technology has helped to transform the region's industrial model as computers get better at performing complex manufacturing tasks.

Unlike in the United States or mainland China, where one spoken language is dominant, Taiwan and its neighbours in southeast Asia operate in hundreds of languages, which makes it harder to collect surveys and feedback in a large, usable data set for developing new software and hardware, says Sun, who was previously a researcher in electrical engineering at the NTHU. "In recent years, it's made it harder to gather the market knowledge needed to create new products, such as consumer electronics like tablets or headphones," he says. "Now, you don't need so much human resource to convert the information into usable data. AI can understand all the different languages at once."

Sarah O'Meara is a writer and editor in London.

Publisher's note: Springer Nature remains neutral with regard to jurisdictional claims in institutional affiliations.

\section{January 2018 \\ The government rolls out its three-year Al Taiwan Action Plan to establish the island as an $\mathrm{Al}$ leader. It aims to prioritize Al innovation and implementation in industry during 2018-21 and invest more than $\$ 300$ million into the field.}

\begin{tabular}{|c|c|c|}
\hline $\begin{array}{l}\text { February } 2018 \\
\text { Taiwan relaxes } \\
\text { regulations for the } \\
\text { employment of } \\
\text { foreign professionals } \\
\text { to encourage talent } \\
\text { recruitment. }\end{array}$ & $\begin{array}{l}\text { March } \mathbf{2 0 1 8} \\
\text { The government } \\
\text { promotes policies to } \\
\text { incentivize investment } \\
\text { in start-ups. These aim } \\
\text { to provide capital, relax } \\
\text { visa and employment } \\
\text { laws, encourage local } \\
\text { and foreign cooperation } \\
\text { and help investors to } \\
\text { cash in on successes. }\end{array}$ & $\begin{array}{l}\text { June } 2018 \\
\text { MOST establishes the } \\
\text { Taiwan Tech Arena to } \\
\text { support start-ups in } \mathrm{Al} \text {, } \\
\text { semiconductors and } \\
\text { software development } \\
\text { and to help them to } \\
\text { forge international links. }\end{array}$ \\
\hline
\end{tabular}

January 2019
Launch of a three-year
scheme to relocate
Taiwanese businesses
back to the region.
Policies involve
assisting firms with
resources such as
land, water, electricity,
labour, taxation and
financing.

\section{May 2019}

Taiwan's cabinet approves a 4-year, \$658-million spending plan for $5 G$ technology to increase the region's digital competitiveness. 